\title{
The Reformation and National Culture: Lithuania
}

In Polish writings the Reformation often appears as a simple opposition to victorious Catholicism, an alternative solution that by countering negative processes (that is the elimination of the national factor by universal forms) and despite failures (the Commonwealth!) influenced the course of events. An historian delving into religious propaganda noticed: 'Together with the Reformation there took place a conspicuous development of writings in national tongues', ${ }^{1}$ and an expert on Lithuania wrote: 'The Reformation made a considerable contribution to national Lithuanian culture by developing writings in the Lithuanian language', ${ }^{2}$ an opinion shared by a Lithuanian researcher. ${ }^{3}$ The cited opinions are confirmed by the growing number of schools, print shops, and books in the national language, that is Lithuanian.

All thirty printed publications in Lithuanian, which appeared in the sixteenth century (1547-1600), were religious (with the sole exception of a decree issued by Margrave George Frederick in 1589; the acts of 1578 sustaining Protestantism in Ducal Prussia ruled by him were to

1 M. Kosman, Reformacja i kontrreformacja w Wielkim Księstwie Litewskim w świetle propagandy wyznaniowej, Wrocław, 1973, p. 8.

2 J. Ochmański, Historia Litwy, Wrocław, 1967, p. 115.

3 I. Lukšaite, Lietuviu kalba reformaciniame judejime XVII a., Vilnius, 1970 (Acta Historica Lituanica, vol. 5). The author is of the opinion that although the motor force of the activity pursued by the Reformation was religion, objectively speaking its representatives contributed to the creation of national Lithuanian culture. 
a certain extent connected with religion). ${ }^{4}$ The majority, albeit not all (Mikołaj Dauksza!), originated from the Reformation circle and were of a somewhat utilitarian nature. They included collections of prayers, songs, a catechism... There is no polemic literature but also not a single work countering the Catholic side. The papal nuncio Julius Ruggieri, in Poland at the end of the 1560s, noticed in his report (1570?): 'Up to now no one has written in it [that is Lithuanian]'. 5 This statement was untrue but familiarity with (and accessibility to) Lithuanian publications was limited. Apparently, there were two reasons for this state of things, both remaining in a different relation to each other. The fundamental reason was the auxiliary character of the first 'Lithuanica'. Both sides, Protestant and Catholic, regarded them as support for the clergy working among the faithful. This situation changed at the turn of the 1620 s and the appearance of works by Konstanty Szyrwid: Dictionarium trium linquarum in usum studiosae iuventutis (1629) and Clavis linquae Lituanicae (1630). The second factor was the absence of an all-Lithuanian language, including a literary one. The above-mentioned nuncio stated: 'Four languages - Lithuanian, Samogitian, Prussian and Livonian - similar and comparable, are actually a single tongue although they differ in many respects' ${ }^{6}$ A commentary by Mikołaj Dauksza (Mikalojus Daukša) to the second edition of his translation of the catechism by Jakub Ledesma depicts the difficulties encountered while deciding to use one of the languages: 'I have heard quite a few saying: "I do not understand the catechism translated by Rev. Dauksza, the canon of Samogitia, since he translated it into the Samogitian" and I was asked to translate it into the Lithuanian'. ${ }^{7}$ Interestingly, the growing number of Lithuanian books in Lithuania from 1547 to 1750 appears to be independent from the deterioration of the dissident camp. More, in consistently Protestant Ducal Prussia the seventeenth century was a time of regress (see table). ${ }^{8}$

4 Data about Lithuanian writings come from: Knygos lietuviu kalba, vol. 1: 1547-1861, Vilnius, 1969, passim; Drukarze dawnej Polski od XV do XVIII wieku, fasc. 5: Wielkie Księstwo Litewskie, ed. by A. Kawecka-Gryczowa, K. Korotajowa, and W. Krajewski, Wrocław, 1959, passim.

5 J. Gintel, Cudzoziemcy o Polsce. Relacje i opinie, vol. 1, Cracow, 1971, p. 141.

6 Ibid., p. 142.

7 J. Ledesma, Kathechismas, arba Mokslas kiekvienam krikszczionii priva-lus, paraszitas per [...], Vilnius, 1595.

8 Knygos lietuviu kalba, op. cit., vol. 1, p. XII. 


\begin{tabular}{c|c|c|c|c}
\multirow{2}{*}{ Years } & \multicolumn{3}{|c|}{ Place of publication } & \multirow{2}{*}{ Total } \\
\cline { 2 - 4 } & GDL & Ducal Prussia & Others & \\
\hline $1547-1600$ & 8 & 22 & - & 30 \\
$1601-1650$ & 14 & 6 & 1 & 21 \\
$1651-1700$ & 17 & 16 & 1 & 34 \\
$1701-1750$ & 28 & 111 & 7 & 146 \\
$1751-1800$ & 142 & 124 & 2 & 268
\end{tabular}

The cited data, despite the ostensibly paradoxical nature of the statement, are not decisive for the role or significance of the Reformation in the history of Lithuanian writings. In order to accomplish this task it is necessary to closely follow assorted paths of the social development of the Grand Duchy of Lithuania, with particular attention paid to turnabouts involving reflections on the directions and forms of the Reformation movement, and a definition of the place, which the Lithuanian factor occupied in its total impact, or rather the objective consequences of the initiated undertakings.

Research conducted by Marceli Kosman demonstrated that the Reformation in the Grand Duchy of Lithuania differed basically from its West European and even Polish counterparts. In contrast to the latter two, a prominent role was not played by essential socio-economic or even ideological factors. 'The lords turned towards the Reformation not so much owing to a conflict with the Church but because the Protestant creed was more beneficial for them and the state'. ${ }^{9}$ This was the reason why the Lithuanian Reformation was directed both against the weak local Catholic Church and the Russian Orthodox Church. True, the latter was going through a period of stagnation and even regress, but the influx of the Ruthenian element in the towns and the effective impact on the Lithuanian countryside went on.

The Reformation movement, whose onset in Lithuania should be sought in the middle of the sixteenth century (the first church was erected in Brześć on the Bug in 1553), was rather artificial: it was inspired by the Lithuanian magnates and expanded under their protection and thanks to the activity of people who were partly foreigners. 'The first humanists

9 Kosman, op. cit., p. 39. 
- Kulwiec, Rapagellanus, Jerzy of Ejszyszki - were Lithuanians... after 1553 we notice almost excessively Poles'. ${ }^{10}$ More, they were active in an environment that to a large degree remained under the impact of the Polish culture.

The distinct divergence between the Lithuanian books published in Königsberg and the ones issued in Lithuania confirms the thesis about the character of the Lithuanian Reformation inspired by local magnates.

Starting with the fifteenth century, the gentry in the Grand Duchy of Lithuania not only accepted privileges modelled on Polish ones, but also customs and language that relegated Lithuanian from the vernacular and Ruthenian - from official acts. The cited nuncio Ruggieri noted: 'The royal chancery in Lithuania writes in Ruthenian, as do the citizens with the exception of those who prefer to write in Polish'. ${ }^{11}$ The young generation, or at least the young lords, can be regarded as culturally Polonised, without forgetting, however, a vital awareness of national distinctness. On 10 May 1570, Mikołaj Krzysztof Radziwiłł “Sierotka”, a citizen of the Commonwealth and a Lithuanian, wrote to his brother, Jerzy Radziwilł, the future bishop of Cracow and cardinal:

\footnotetext{
Rev. Djarga sent me a book written by Franciscus Turrianus contra Volanum, with the first part dedicated to the bishop of Vilnius [Walerian Protaszewicz], and the second to Your Lordship. I noticed duo errata. First, instead of Radivilianum - Radivilium, second - Polonum. Instruct them, Your Lordship, that whenever they want to dedicate something to someone they should first learn how to call them and not obliterate their nationality. Your Lordship is a Lithuanian and not a Pole. May Your Lordship wish for your nation to be acknowledged. The Poles suppose that there is no one superior and are willing to stifle Lithuania. Be so kind as to elevate gentem suam whenever possible. Our deceased father [Mikołaj Radziwiłł Czarny] made great efforts for extra nationes to know about Lithuania as they do about Poland [...]. I am certain that there Your Lordship is known not as a Pole but as a Lithuanian. ${ }^{12}$
}

The premises of this study make it possible to analyse factors that determined the path of the development of Lithuanian society. Without

10 Ibid., p. 56.

11 Gintel, op. cit., p. 141.

12 Kórnik, Library of the Polish Academy of Sciences, Ms 1341, p. [18]. 
negating the force of the impact and attraction of the Polish cultural model we may be entitled to assume that its acceptance was determined by its approval of the ruling dynasty. Just as important was susceptibility to foreign models. In the past, the Lithuanian language was supplanted by the language of conquered Rus', while in the sixteenth century the victor was Polish culture. This does not resolve the dilemma: Polish or Lithuanian! Rather: Polish or Ruthenian, which is significant due to the fact that it was based on a concurrence of ethnic and religious borders (with the exception of the towns). It is simply impossible to ignore the fact that first books were published in Vilnius in Cyrillic script (1525 Apostol; Malaya nabožnaya knižnica - the printing shop of Franciszek Skoryna) as well as that this occurred more than half a century prior to the appearance in Lithuania of printed writings in the Lithuanian language. Priority was ascribed to the Jesuit (!) Catechismus catholicorum by Petrus Canisius, printed more than thirty years after the establishment of a Protestant church in Brześć Litewski, ${ }^{13}$ at a time when the domination of the Polish language in the Grand Duchy became a fact. Already the I Lithuanian Statute (1529), written in official Western Old Ruthenian, was translated only into the Latin and then into the Polish (1532). There was no need to translate it into the Lithuanian, which was unrecognized in courts and chanceries. During the 1590s Mikołaj Dauksza wrote in a foreword to a translation of Jakub Wujek's Postilla catholicka (Vilnius, 1599, Academic Printers):

\footnotetext{
Sam nasz litewski naród dla umiejętności języka polskiego i w nim biegłości, do jakiego zaniedbania, opuszczenia i niemal odrzucenia język swój własny przywiódł, każdy snadnie widzi, lecz jak słusznie, nie wiem kto pochwali [...]. Lecz to nie tym umysłem mówię, abym miał ganić biegłość i umiejętność postronnych języków [...], zwłaszcza polskiego, który nam przez ono miłe zjednoczenie WX naszego ze sławną Koroną Polską niemal przyrodzony jest, ale tylko ganię zaniedbanie a zbrzydzenie i niemal odrzucenie języka naszego właśnie litewskiego.
}

13 The first Ruthenian print shop - Franciszek Skoryna, Vilnius, 1524-25; dissident print shop - Bernard Wojewódka, Brześć Litewski, 1553-54; Catholic print shop - the Radziwiłłs, Vilnius, 1576-86. The Canisius publication was issued in the dissident print shop of Daniel of Łęczyca in Vilnius, in 1585; translated into Latvian by Erdman Tolgsdorf. 
In time, familiarity with the official language also began to vanish in society. Already during the Sejm session of 1565/66 the gentry from the Podlasie region requested Sigismund II Augustus not to send instructions in a strange language. In the seventeenth century this troublesome injunction was universally ignored, with only the introduction and end of a given act (instruction) being written in Ruthenian (Cyrillic alphabet) while the contents were in Polish and printed in the Latin alphabet. In the towns assimilation followed a similar course. The wilkierz (a set of records of the laws) of Vilnius published in 1552 was written in Polish although this does not signify an exclusive or even dominating rank of this language in the town in question: 'Wywotanie or achtowanie is to be presented by aldermen in Polish, Lithuanian and Ruthenian, so that all who listen would understand'. ${ }^{14}$ In the middle of the seventeenth century 53 per cent of the town acts in Vilnius were written in Polish, 37 per cent - in Latin, and 10 per cent in Ruthenian. ${ }^{15}$ After 1737 sermons were no longer delivered in Wilno in Lithuanian, a fact that should be linked not so much with the national question as the linguistic situation prevailing in the town.

In the countryside Polish culture (and in Livonia German culture) made little headway, a situation that had multifold consequences. The Polishness and thus the distinctness of the Church favored the retention of old beliefs. The access of the upper strata to the circle of Polish culture, with its simultaneous rejection by the dependent population, hampered the creation of the Lithuanian nation and, at the same time, determined the social form of the national revival movement in Lithuania during the nineteenth and twentieth centuries. By preserving its traditional structure, the countryside proved to be sufficiently strong not to succumb to foreign (Polish) impact, which was particularly external owing to the fact that it belonged to the upper social strata. Such features, however, were not part of - or to a much less contrasting degree - the Ruthenian culture of one of the nations ruled by Lithuanian dukes. Its successes, however, were weakened by bonds existing in the countryside; hence Polish language and culture quite often followed their Ruthenian counterparts.

14 S. Górzyński, Obowiązki kupców w świetle opisania o skladziech i starych drogach króla Zygmunta Augusta z roku 1565, Warsaw, 1939, p. 27.

15 M. Łowmiańska, Wilno przed najazdem moskiewskim z roku 1655, Vilnius, 1929, p. 84 . 
The (cultural) Polonisation of the Lithuanian magnates already in the middle of the sixteenth century and that of a considerable part of the Lithuanian gentry was supported by the former's willingness to retain political relations with the Crown and the latter's institutional rapprochement. This, in turn, together with the character of the Reformation movement, somewhat imposed from above, possessed typical consequences for the accepted forms of activity. In references to writings it acknowledged, alongside Latin, the Polish language as fundamental - an unavoidable decision. One of the premises was the nationality or rather cultural circle from which the ideological opponent attacked in the writings originated. In view of the intellectual weakness of the Russian Orthodox Church at the time the opponent was the environment connected with the Catholic Church, people who confronted - and could be assailed in return - only in a language widely known to society and intellectual centres. In the Crown and Lithuania this language, alongside Latin, could be Polish. Just as important was the mentioned nationality of the Reformation activists as well as persistent efforts to create an oecumenical Church. ${ }^{16}$

The second premise was the Polonisation of the stratum that constituted the basic field for the activity of, and support for the Lithuanian Reformation. The frailty of the Catholic Church in sixteenth-century Lithuania, which was tantamount to weak education, excluded, for all practical purposes, the possibility of addressing the Lithuanian peasant directly, via the printed word. Hence the utilitarian character of scarce Lithuanian publications, reinforced by the religious indifferentism of the Lithuanian peasant.

A merge of three elements - the originally artificial character of the movement, the extra-Lithuanian points of reference (Königsberg, which in the sixteenth century was a centre of Polish writings, the Crown and Western Europe in general) and the considerable cultural Polonisation of a circle of people capable of taking part in this 'intellectual adventure', i.a. the Reformation, determined an outcome unfavourable for Lithuanian culture. It reinforced the impact of Polish books from the Crown, intensified its production in Lithuania and, at the same time, hampered the development of original Lithuanian works written in Lithuanian. On the state level this situation objectively favoured the emergence of cultural unity, that is the creation of the gentry nation of the Commonwealth.

16 I.a. Mikołaj Radziwiłł "Czarny” - Kosman, op. cit., p. 55. 
Polishness enhanced the Reformation (and the Counter-Reformation), while the latter expanded the range and force of its effect.

From the onset of the Reformation in Lithuanian lands (mid-sixteenth century) to its basic defeat (mid-seventeenth century) there appeared according to probably incomplete estimates ${ }^{17}$ some fifty one Lithuanian books. In Lithuania itself they totalled twenty two, mainly translations of Polish books or universal publications devoid of national traits. Among eight Lithuanian books issued in the sixteenth century (1585-1600) by printers located within the frontiers of the Grand Duchy four were direct translations from the Polish (Mikołaj Rej and Jakub Wujek), one - a Polish and Lithuanian catechism by Melchior Pietkiewicz, and three were translated from the Latin (Petrus Canisius and Jakub Ledesma). ${ }^{18}$ Greater significance due to their originality could have been attached to publications from Königsberg - predominantly those by Martynas Mažvydas (seven) and Jonas Bretkunas. Studies on the history of religious propaganda indicate, however, that: 'At last some Königsberg editions, rather carelessly prepared, did not meet with great interest within the Polish milieu for which they were intended. This was the outcome of the fact that Hohenzollern's co-workers did not always know the recipients of their works in Poland and Lithuania'. ${ }^{19}$ Consequently, with certain exceptions, Lithuanian publications did not create a basically different quality in the awareness of the readers, capable of competing with Polish books. On the contrary, due to the Polishness contained therein they paved the path for original works from the Crown, whose numbers dominated. Each Lithuanian book corresponded to multiple Polish editions published in Lithuania or the Crown, which then reached Lithuania.

The publication of the main work of the Reformation in Lithuania already in 1563, namely, the Brześć or Radziwiłł Bible in Polish, was

17 Not a single print intended for the Kiejdany secondary school and produced by the local printers has survived. Only one publication from this print shop is known; presumably, it was not an isolated case.

18 M. Rej, Postilla lietuwiszka [...], Vilnius, 1600, printer: Jakub Markowicz, Parts 1-3; J. Wujek, Postilla catholicka, Vilnius, 1599, Academic Printers; Pietkiewicz, Polski z Litewskim katechism [...], Vilnius, 1598, printed by S. Wierzejski; P. Canisius, Catechismus catholicorum, Vilnius, 1585, printed by Daniel of Łęczyca; J. Ledesma, Kathechismas [...], Vilnius, 1595, issued by Academic Printers; idem, Trumpas budas pasisakimo [...], Vilnius, 1595, issued by Academic Printers.

19 Kosman, op. cit., p. 62. 
not so much a reflection of the state of things within culture, prevailing among potential readers. It also signified the liquidation of a national and culturally distinct Lithuanian programme. Bernard Wojewódko published in the Brześć print shop (1553-54) 'popular and accessible dissident writings exclusively in the Polish language'. ${ }^{20}$ This was the first dissenter print shop set up in Lithuania. The one established in Nieświez by Mikołaj Radziwiłł "Czarny" issued Polish prints already from 1563; only two publications in the Cyrillic alphabet from 1562 are extant. These facts are significant since the leading position of Radziwitł in the Lithuanian Reformation movement does not give rise to any doubt. The Polish language also dominated in the remaining dissident print shops... Among eight Lithuanian books published in the Grand Duchy, three were produced by the Academic Printers, one, although Catholic, was printed by Daniel of Łęczyca, three were produced in the print shop of Jakub Markowicz, and one was published by Stanisław Wierzejski. ${ }^{21}$

The seventeenth century multiplies doubts regarding the contribution made by the Reformation to Lithuanian culture (writings). In 1601-50 there appeared fourteen books in Lithuanian, with only one (Salomon Rysiński, Katekizmas, 1624) originating in the dissident environment. More, the end of the 1620s witnessed the publication of works by Konstanty Szyrwid (Konstantinas Sirvidas), Dictionarium, Clavis linquae, published by Academic Printers, which finally, and from the viewpoint of the topic, constitute a caesura in the history of Lithuanian writings. This was the first time that use was made of Latin typeface in place of its Gothic predecessor and lexicographic works in Lithuanian were introduced. During this period the Königsberg centre was undergoing a regress. Among six Lithuanian publications two were decrees issued by Władysław IV Vasa, three - religious works translated from the German (a visible sign of a decline of the Polish centre), and the sixth was the equally indifferent Psatterz Dawida. ${ }^{22}$ The range of the work conducted by churches in the Lithuanian environment was considered in 1617 by the Council of the Evangelical Reformed Brethren, which enacted: 'Upon the occasion of visitations the reverend superintendent is to examine the minister's library to see what sort of books it contains.

20 Drukarze..., op. cit., p. 252.

21 See note 18 above.

22 Der Psalter Davids Deutsch und Littawisch. Psalteras Dovido Wokischkai bei Lietuwischkai [...], Karaliautzoje Prussu [Königsberg], 1625, Lorenz Segebade. 
Among those Brethren who do not understand Latin he is to seek papist and nowokrzczeńskie books to prevent them from being used for sermons, and urgently make sure that each should have the Brześć Bible, the New Testament, Postylla Żarnowcowa by Rev. Kraiński, and Katechizm Gilowski. ${ }^{23}$ No mention was made of Lithuanian publications, probably in connection with their availability.

The question of ministers speaking Lithuanian was to persist among the Calvinists of Lithuania throughout the whole seventeenth century. In 1624 the Synod, 'aware [...] of the needs of God's Church and the scarcity of those using the Lithuanian language to speak the word of God permitted Rev. Krzysztof Minwid to be ordained minister after two years of catechisation'. ${ }^{24}$ In 1631, 'taking into account [...] the vota and desideria of pious people living near Kiejdany, who would like the evangelical service to be celebrated in Lithuanian, [the Synod] appoints ex Alumnatu Slucensi a pious young man, Jan Borzymowski, who at the church in Kiejdany will say munus Cathecheticum in Lithuanian'. ${ }^{25}$ Half a century later, a request was addressed to Ludwika Karolina née Radziwilł, wife of the Margrave of Brandenburg, 'for a third servant of God speaking Lithuanian in Birże [...] as well as a catechist fluent in the Lithuanian language'. ${ }^{26}$ Significantly, this reduction of the number of educated people familiar with the Lithuanian language affected education.

In the first half of the seventeenth century the dissidents possessed, apart form the school in Vilnius, also two specific institutions that influenced local society: in Słuck and Kiejdany, where it experienced

23 New Testament, probably an edition from 1589, in which B. Budny abandoned the Unitarian stand. Grzegorz from Żarnowiec, Postylla albo wyktady ewanieliej niedzielnych i na święta [...], Parts 1-3, Cracow, 1580-82, with Supplement (?) as Part 4; P. Gilowski, Wyktad katechizmu kościota chrześcijańskiego, Cracow, 1583; A. Kawecka-Gryczowa indicates Żejmy or Vilnius, 1605 (K. Kraiński, Postylla kościota powszechnego apostolskiego, Parts 1-13, Łaszczów, 1608-17), but connects the synod text with Postylla Żarnowcowa by Paweł Kraiński, clearly distinguishing Katechizm Gilowskiego. Warsaw, National Library (hereafter, BN), BOZ, Ms 803, 'Acta Synodu 1617', p. 76.

24 Warsaw, University Library, Ms 478, 'Consens Synodowy na inaugurację x. Krzysztofa Minwida', 1624.

25 BN, BOZ, Ms 803, 'Acta Synodu 1631', p. 241.

26 Quoted after Lukšaitè, op. cit., p. 57. 'Puncta podane [...] Comisarzom [...] Margrabiny Brandenburskiej', 11 June 1686. 
periodic difficulties. ${ }^{27}$ Furthermore, a number of schools adjoining local churches aimed at producing alumni. Surprisingly, despite the absence of people capable of teaching in Lithuanian, the language was omitted in the secondary school curriculum. It was ignored in the curriculum of the Kiejdany school in 1629 and 1685, and in Porzadek szkót ewangelickich $w W X L .{ }^{28}$ In order to respond to requests formulated by the Kiejdany Calvinists an alumnus was brought over all the way from Słuck! In 1646, the reorganisation of the Kiejdany school mentioned only a Slavonic language to be taught by a certain Rudzki. This state of affairs did not change in subsequent years. In 1686 a letter written in Birże and addressed to Ludwika Karolina, asked: 'Since we have very few Servants of God, especially those fluent in Lithuanian, and their number continues to decrease, we request Your Ladyship to provide for the children of God who would like to learn in Lithuanian [...]'. ${ }^{29}$ Not until the end of the seventeenth century in Königsberg and at the beginning of the eighteenth

27 H. Wisner, 'Lata szkolne Janusza Radziwiłła. Przyczynek do dziejów szkolnictwa kalwińskiego na Litwie w pierwszej połowie XVII wieku', Odrodzenie i Reformacja $w$ Polsce, 14, 1969, pp. 183-94. Data concerning the Słuck school are supplemented in: Warsaw, University Library, Ms 503: 'Kopia funduszu Janusza Radziwiłła [...] na wybudowanie kościoła i szkoły ewangelickiej', 12 May 1617; 'Inwentarz zboru słuckiego i szkoły', 1623; 'Extract listu księcia Krzysztofa Radziwiłła danego ks. Dobrzańskiemu szkole słuckiej służącego na zł 430’, 3 August 1623; 'Kopia funduszu księcia Krzysztofa Radziwiłła na szkołę słucką z wyrażeniem jurgieltu dla profesora i katechisty', 13 November 1623; 'Kopia postanowienia Krzysztofa Radziwiłła o wiosce Bronowicze na zbór i szpital słucki zapisanej', 22 November 1624; 'Fundusz na szkołę Krzysztofa Radziwiłła', 1625. An essential change should be introduced in reference to the school in Kiejdany. Contrary to heretofore opinion claiming that the school was established in 1625 it should be accepted that it existed already prior to 1620 , as evidenced in a letter written by Balcer Krośniewicz to Krzysztof Radziwiłł in Birże on 21 March 1620: 'In Kiejdany $[\ldots]$ the school will collapse totally. There are no funds for paying the teacher. The manor house supplies nothing, although originally it did so. After the inspection it appeared to all that I too requested Your Lordship to turn the grain left behind by the deceased Mitek into provision for school praeceptores'. Warsaw, Central Archives of Historical Records (AGAD), Radziwiłłs' Archives (AR), V, vol. 169, no. 7801.

28 BN, BOZ, Ms 803, 1. 312, 'Porządek szkół ewangelickich w WXL, a osobliwie w Słucku [...]', 26 June 1629; S. Tworek, 'Programy nauczania i prawa gimnazjum kalwińskiego w Kiejdanach z lat 1629 i 1685', Odrodzenie i Reformacja w Polsce, 15, 1970, pp. 223-36.

29 Quoted after Lukšaitè, op. cit., p. 57. 'Puncta podane [...] Comisarzom [...] Margrabiny Brandenburskiej', 11 June 1686. 
century in Kiejdany were preparations made to train Calvinist clergymen to work among the Lithuanian peasantry.

From 1579 the Vilnius Academy included a shelter for poor students and a diocesan seminary for candidates who intended to work among the common people. Nonetheless, only young Ruthenians were granted (1579) permission to learn reading and writing in their native tongue.

Summing up: although there are no doubts that the first Lithuanian prints were produced by the Reformation milieu, this fact cannot determine their final assessment. In reality, the publications in question constituted a small fragment of cultural life, especially in view of the fact that owing to their (considerable) secondariness they did not comprise a serious source of inspiration. More, a foundation composed of translations from the Polish objectively hampered the progress of original works and proved conducive for Polish infiltration. The meaning of this fact was even greater considering that the basic current affecting society was Polish-Latin. In other words, the essential consequence of the appearance of the Reformation in Lithuania was not support for, but a further deterioration of Lithuanian qualities, halting the development of national Lithuanian culture and providing conditions that objectively favoured the creation of the culture of a single nation - that of the Commonwealth of Two Nations. Without negating the primacy of attempts at producing Lithuanian writings this fact should be ascribed an inferior rank. A comparison of the gains and losses for Lithuanian culture caused by the Reformation movement ultimately yields a negative effect.

\section{Translated by Aleksandra Rodzinsska-Chojnowska}

First published as: 'Reformacja a kultura narodowa: Litwa', Odrodzenie i Reformacja $w$ Polsce, 20, 1975, pp. 69-79. 